\title{
UPTAKE OF INSECTICIDES AND FUNGICIDES BY IMPREGNABLE AND REFRACTORY CONIFEROUS WOOD SPECIES TREATED WITH COMMERCIAL BIO-BASED EMULSION GEL FORMULATIONS
}

\author{
Daoü̈a Messaoudi', Katia Ruel ${ }^{1,2}$, Jean-Paul Joseleau ${ }^{1,2, \$}$
}

\begin{abstract}
Even in dry state, wood can be prone to biological degradation. Preservation is a prerequisite to confer protection and durability to wood. This is conventionally achieved by impregnating the wood with pesticides. A key point in these treatments is the complex process of wood penetrability. We focused on the relation between the penetration of wood preservatives, wood microstructure, and the physical characteristics of formulations in the impregnation of the easily impregnable pine (Pinus sylvestris), and the refractory spruce (Picea abies). In this work, specimens from the two species were impregnated with three types of commercial bio-based emulsion gels formulations containing insecticides and fungicides. The effect of treatment method using dipping, surface spraying, and vacuum-impregnation, on the retention of the active agents was analyzed. Visual assessment, and qualitative and quantitative analyses of cypermethrin, permethrin and propiconazole by gas liquid chromatography coupled to mass spectroscopy showed enhanced penetration of the active agents, and revealed differences of penetration performance of each agent. The suitable combinations of solvents and surfactants used in the bio-based formulations enabled rapid wood penetration and high yields retention. The capacity of penetration and retention of our gel formulations is discussed in terms of the connectivity of the conducting cells network of the two wood species.
\end{abstract}

Keywords: Emulsion gels formulations, fungicides, impregnation, insecticides, Picea abies, Pinus sylvestris, wood microstructure, wood preservatives.

\section{INTRODUCTION}

As a natural material, wood is degradable under the action of microorganisms, insects, and natural borers. Protect wood from microbial attack is a prerequisite to achieve adequate performance and durability, particularly in exterior applications or furniture making (Richardson 1993). Penetration of agents is the key-impregnation. Several factors affect the efficacy of the treatments such as the impregnable or refractory nature of the wood species, the characteristics of the pesticide formulation, the processes of liquid transportation in wood cells and the type of technology implemented (Evans 2003). The main types of treatment technologies include surface coating such as dipping, spraying, brushing, or vacuum-impregnation, the latter being particularly used for refractory species, and even by incision. Preservative penetrations (Civardi et al. 2015) depends on the solvent type such as water-based or organic solvent-based solutions and or suspensions, supercritical carbon dioxide (Kang et al. 2005), hydrogel formulations (Obounou Akong et al. 2013), emulsions (macro-, microand nano-) (Du et al. 2016), as well as on the polarity of the active agents (Zhang et al. 2006). Researchers have long tried to establish a relation between penetrability of liquids and wood anatomical structure (Wardrop and Davies 1961, Koran 1989, Olsson et al. 2001, Hass et al. 2009). For example, hardwoods and softwoods ex- 
hibit different susceptibilities to liquid penetrability and absorption (Comstock and Côté 1968, Lehringer et al. 2009a, Lehringer et al. 2009b). Moreover, differences occur within softwood species leading to classification in easily penetrable and refractory species (EN 350 2016). The relative proportion and distribution of sapwood $v s$ heartwood been suggested to account for the respective penetrability of these two wood species (Rhatigan et al. 2004, Zlahtic 2017). However, the relation between penetrability and wood anatomical microstructure is still largely unexplained.

The objective of the present study was to investigate the respective behavior of the non-refractory pine wood (Pinus sylvestris) and the refractory spruce wood (Picea abies) impregnated by three types of commercial preservative formulations, and to evaluate the performance of microemulsion gel formulations on the two softwood species. These aqueous formulations with low toxicity, non-volatile, odorless, and hypoallergenic (Griggs et al. 2017, Teng et al. 2018), were under the form of a bio-based isoparaffinic microemulsion gels. In this type of aqueous gel formulation, the olefin component plays a decisive role in the diffusion penetration of the active agents. In this study, the depth of penetration and extent of uptake and retention of the active agents were evaluated as a function of three modes of application and conditions, namely, dipping, surface spraying, and vacuum-impregnation. The capacity of penetration and diffusion of the pyrethroids cypermethrin, and permethrin relative to propiconazole, were evaluated.

The impact of emulsion gels formulations on the performance of the treatments was quantified. Such data should contribute to the basic understanding of the susceptibility of different wood species to pesticide applications and show the interests of emulsion gel formulations in improving wood preservation treatments.

\section{MATERIALS AND METHODS}

\section{Wood materials and specimen preparation}

Sapwood of the easily impregnable pine (P. sylvestris), and a predominant heartwood to sapwood mixture of the refractory spruce (P. abies) were used. Spruce contained sapwood/heartwood ratios of 50/50, 60/40 and 20/80. All specimens were prepared from planks cut longitudinally, 10 specimens of pine and 12 of spruce, all taken from different wooden blocks. They measured $480 \mathrm{~mm}$ x $200 \mathrm{~mm}$ x $50 \mathrm{~mm}$, and $150 \mathrm{~mm}$ x $60 \mathrm{~mm}$ x 15 $\mathrm{mm}$ (longitudinal $\times$ radial $\times$ tangential) $($ Figure 1$)$.

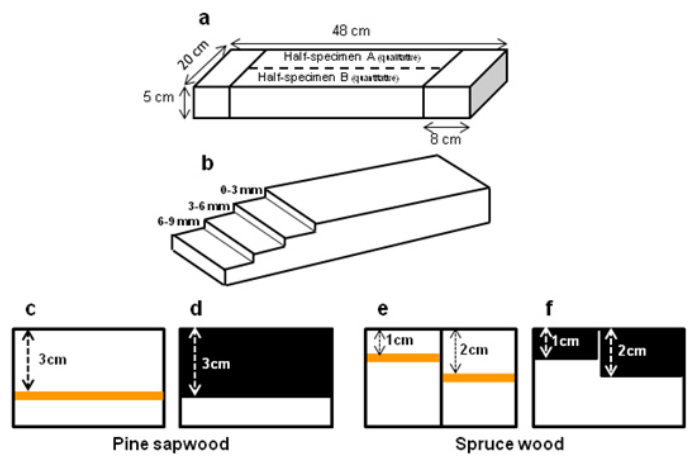

Figure 1: Preparation of specimens for assessing penetration, and for monitoring quantitative distribution of propiconazole and permethrin. (a) General dimensions of specimens for assessment of penetration $48 \mathrm{~cm} \mathrm{x}$ $20 \mathrm{~cm} \times 5 \mathrm{~cm}$; half specimen A will be used for qualitative analysis and half specimen B, for quantitative; (b) mode of sampling for analyses of liquid bio-based micro-emulsion (cypermethrin) treated samples; (c) - (f) sampling for qualitative and quantitative analyses of pine sapwood (c-d) and spruce (e-f) : the yellow lines show the $2 \mathrm{~mm}$ thick sampling at a distance of $3 \mathrm{~cm}$ for pine (c), and 1 and $2 \mathrm{~cm}$ for spruce (e), respectively. The black rectangles represent the sampling on a thickness of $3 \mathrm{~cm}$ in pine (d) and $1 \mathrm{~cm}$ and $2 \mathrm{~cm}$ in spruce

(f) used for quantitative evaluation. 
To evaluate the effect of thickness on the impregnation, specimens of $40 \mathrm{~mm}$ and $60 \mathrm{~mm}$ in thickness were prepared (Table 1).

The specimens were conditioned in a climate chamber at $20{ }^{\circ} \mathrm{C}$ and $65 \%$ relative humidity (RH) for 7 days prior to testing. Measurement of humidity and density was done on $8 \mathrm{~cm}$ samples before impregnation. Impregnation was performed by different application processes: dipping, spraying and vacuum-pressure. Spraying was applied on one or two faces of specimens and the quantity of product absorbed was estimated by weighing before and after spraying treatment. They were stored at $20{ }^{\circ} \mathrm{C}$ and $65 \% \mathrm{RH}$ for 7 days after treatment. Net solution absorption was determined by weighing before and after impregnation. Macroscopic penetration was evaluated visually on samples cut transversally from the specimens at $8 \mathrm{~cm}$ from the extremities. Transverse sections from the treated specimens were photographed to enhance delineation of the penetration. For biochemical analyses, the specimens were stored for 21 days at $20^{\circ} \mathrm{C}$ and $65 \% \mathrm{RH}$, and humidity and density measured before quantitative and qualitative analyses. Ten specimens of spruce and 8 of pine were analyzed. Two specimens of both wood species sprayed on their two faces were cut lengthwise and the analyses performed each half-specimen, so as to monitor active agents retention according to penetration depth.

\section{Preservative treatments}

Three commercial formulations were used: formulation XILIX ${ }^{\circledR}$ LabF2018_008 from Adkalis, Blanquefort (France) (Messaoudi et al. 2018) : a biodegradable (Mohamad-Shahimin and Siddique 2017) emulsion-gel consisting of synthetic hydrocarbon iso-paraffinic, co-solvent plus water and a cellulose ether thickener (c.a ., 1\%), and active agents (c.a., 2 \%). (E.U norm NF EN 16640-2017 and International Norm ASTM D6866$2020)$. The active agents were the fungicide propiconazole $(1,2 \%, \mathrm{w} / \mathrm{w})$ and the insecticide permethrin $(0,5$ $\%, \mathrm{w} / \mathrm{w}$ ). The second commercial formulation was AXIL ${ }^{\circledR}$ LAB2013 131 (European class 1 for outdoor and hazards uses in wetting conditions above ground) from Adkalis (over $\overline{60} \%$ bio-based) liquid microemulsion at $8 \%$ cypermethrin plus $9 \%$ fungicide agents, used here at a $4 \%$ dilution rate $(\mathrm{w} / \mathrm{v})$ in water. The third formulation was the gel XILIX ${ }^{\circledR}$ LabF2018_009 ${ }^{\circledR}$, containing insecticide plus fungicide $(c a .2,4 \%)$.

The uptake of the preservative emulsion gel formulations in pine and spruce wood was measured under three different treatment modes, as shown in Table 1. Surface spraying was implemented with the XILIX ${ }^{\circledR}$ formulations. The gel was applied at a pressure of 20 to 40 bars. The amount of gel deposited was $400 \mathrm{~g} / \mathrm{m}^{2}$ to $450 \mathrm{~g} / \mathrm{m}^{2}$, as determined by weight variation before and after spraying. In the vacuum-impregnation process, the specimens were treated in an autoclave (T\&G Distribution, bvba) where they were impregnated with the desired formulation, and subjected to the following cycle: initial vacuum of $0,02 \mathrm{MPa}$ for $20 \mathrm{~min}$, followed by filling the chamber with the formulation product $(600 \mathrm{~L})$. Pressure was adjusted to 1,2 MPa maintained for 70 min, followed by evacuation then under vacuum of $0,02 \mathrm{MPa}$ for $25 \mathrm{~min}$, and draining of the autoclave. The specimens were then dried in the air.

\section{Monitoring propiconazole, permethrin and cypermethrin distribution by qualitative and quantitative analyses}

Visual control of the extent of penetration of the formulations in the samples $(20 \mathrm{~cm} \mathrm{x} 8 \mathrm{~cm} \times 5 \mathrm{~cm})$ was underscored by photography. Identification and quantification of the active agents was carried out with a Thermo Scientific Trace 1310 gas-chromatograph apparatus coupled to an ISQ mass spectrometer. The GC was equipped with a Restek capillary column (Rxi-5 ms, $30 \mathrm{~m}$ x $0,25 \mathrm{~mm}$ x 0,25 $\mu \mathrm{m}$ ) connected to the XCALIBUR software. Reference standard solutions $(10 \mathrm{mg} / 10 \mathrm{ml}$ hexane) of propiconazole (Sigma-Aldrich 45642), permethrin (Sigma-Aldich 45614), and cypermethrin (Supelco 36128), were used with deltamethrin (Sigma-Aldrich 45423 ) as the internal standard.

Specific distribution of the amount of propiconazole and of permethrin was estimated by GC-MS on specimens of $48 \mathrm{~cm} \times 20 \mathrm{~cm} \times 5 \mathrm{~cm}$ that had been stored for 7 days at $20^{\circ} \mathrm{C}$ and $65 \% \mathrm{RH}$ following spraying treatment. The specimens were then stored again for a period of 21 days at $20^{\circ} \mathrm{C}$ and $65 \% \mathrm{RH}$ before analysis of the amounts of propiconazole and permethrin, or cypermethrin, respectively. The retention of product was quantified and the repartition of product according to depth was determined on sections of $3 \mathrm{~mm}$ cut at increasing distances from the surface of the specimens (Table 2). Samplings were from 10 specimens of spruce and 8 specimens of pine. For GC-MS analyses, planing shavings were ground in a grinder. To $5 \mathrm{~g}$ ground aliquots 
$100 \mathrm{ml}$ acetonitrile were added and extraction carried out in the automated Thermo Scientific Dionex ASE 350 system followed by sonication for $60 \mathrm{~min}$. After filtration, and evaporation in a rotary evaporator, the dry extract was taken up in isohexane $(2 \mathrm{ml})$, and $100 \mu \mathrm{l}$ of internal standard (deltamethrin $0,1 \mathrm{mg} / 1 \mathrm{ml}$ isohexane) was added to $1 \mathrm{ml}$ of isohexane extract. Determination was done on slices of $2 \mathrm{~mm}$ taken at $3 \mathrm{~cm}$ from the surface on pine, and only at $1 \mathrm{~cm}$ and $2 \mathrm{~cm}$ on spruce since the penetration was limited in the latter (Figure 1c, Figure 1d, Figure 1e, Figure 1f).

\section{RESULTS AND DISCUSSION}

\section{Uptake and retention}

As expected, among the three technologies of impregnation implemented, vacuum-impregnation gave the highest average uptake in both pine (around $55 \%$ vs around $7 \%$ with the other processes) and spruce (around $40 \% v s$ around $6 \%$ with the other processes). Mode of application of formulations clearly affected the yield of retention in both pine wood and spruce wood (Table 1). Indeed, dipping is a non-pressure process in which the six faces of the rectangular specimens are submerged. In this process, the liquid is absorbed into the porous wood under capillary forces that depend on surface tension, and intermolecular forces between the liquid and the surrounding wood surfaces. As a result, the liquid diffuses spontaneously into the solid at a rate which decreases over time by passive diffusion. On the other hand, spraying with the gel (XILIX ${ }^{\circledR}$ LabF2018_009 ${ }^{\circledR)}$ is a process in which the delivery of the formulation as a jet entails a force impact, in $\mathrm{kgp} / \mathrm{cm}^{2}$, (Haller et al. 2002) that enhances penetration and retention. The interest of the present gel in this mode of application resides in the fact that it has a high surface tension in the range of $24 \mathrm{mN} / \mathrm{m}$ to $27 \mathrm{mN} / \mathrm{m}$ (norm EN NF 14370 (2004)) and a thixotropic viscosity. The percentage of uptake when surface application was applied was about double to three times higher by spraying than by dipping.

Table 1: Uptake and retention of active product in pine (P. sylvestris) and spruce (P. abies) wood according to the mode of application.

\begin{tabular}{|c|c|c|c|c|c|c|}
\hline \multicolumn{7}{|c|}{ Emulsion gel formulation AXIL ${ }^{(8)}$ LabF2013_131 } \\
\hline \multirow[b]{2}{*}{$\begin{array}{c}\text { Impregnation } \\
\text { Process }\end{array}$} & \multirow{2}{*}{$\begin{array}{l}\text { Treated } \\
\text { Surface } \\
\left(\mathrm{m}^{2}\right)\end{array}$} & \multirow{2}{*}{$\begin{array}{c}\text { Treated } \\
\text { volume } \\
\left(\mathrm{m}^{3}\right)\end{array}$} & \multicolumn{2}{|c|}{ Retention $\left(\mathrm{g} / \mathrm{m}^{2}\right)$} & \multicolumn{2}{|c|}{ Retention $\left(\mathrm{kg} / \mathrm{m}^{3}\right)$} \\
\hline & & & Pine $^{2}$ & Spruce $^{3}$ & Pine & Spruce \\
\hline Dipping 3 min & 0,0243 & & 238 & 127 & & \\
\hline Dipping $3 \mathrm{~min}$ & 0,0243 & & 234 & 132 & & \\
\hline Dipping 3 min & 0,0243 & & 218 & 156 & & \\
\hline Dipping $15 \mathrm{~min}$ & 0,0243 & & 259 & 165 & & \\
\hline Dipping $15 \mathrm{~min}$ & 0,0243 & & 263 & 170 & & \\
\hline Dipping $15 \mathrm{~min}$ & 0,0243 & & 275 & 180 & & \\
\hline $\begin{array}{l}\text { Vacuum- } \\
\text { pressure }\end{array}$ & & $13510^{-6}$ & & & 646 & 260 \\
\hline $\begin{array}{l}\text { Vacuum- } \\
\text { pressure }\end{array}$ & & $13510^{-6}$ & & & 630 & 290 \\
\hline $\begin{array}{l}\text { Vacuum- } \\
\text { pressure }\end{array}$ & & $13510^{6}$ & & & 637 & 220 \\
\hline $\begin{array}{l}\text { Vacuum- } \\
\text { pressure }\end{array}$ & & $3610^{-6}$ & & & 660 & 300 \\
\hline $\begin{array}{l}\text { Vacuum- } \\
\text { pressure }\end{array}$ & & $3610^{-6}$ & & & 667 & 260 \\
\hline Surface spraying & 0,009 & & 500 & 500 & & \\
\hline Surface spraying & 0,009 & & 500 & 500 & & \\
\hline Surface spraying & 0,009 & & 500 & 500 & & \\
\hline
\end{tabular}

All the specimens of $P$. sylvestris were sapwood; specimens of $P$. abies were mostly heartwood. $4 \mathrm{~cm}$

Specimen dimensions: Dipping and spraying $15 \mathrm{~cm}$ x $6 \mathrm{~cm}$ x 1, $5 \mathrm{~cm}$; vacuum-pressure, $15 \mathrm{~cm}$ x $6 \mathrm{~cm}$ x

(1) Specimen surfaces treated: for dipping, $0,0243 \mathrm{~m}^{2}$; for spraying, $0,009 \mathrm{~m}^{2}$; volumes treated for vacuum-pressure, $135 \times 10^{-6}$ for specimens $1,5 \mathrm{~cm}$ thick, and $36 \times 10^{-5}$ for specimens $4 \mathrm{~cm}$ thick.

(2) Specimens are $15 \mathrm{~cm}$ x $6 \mathrm{~cm}$, either $1,5 \mathrm{~cm}$ or $6 \mathrm{~cm}$ thick. They consist essentially of heartwood. A 
few consist of sapwood/heartwood.

(3) Specimen surfaces treated: for dipping, 0, $0243 \mathrm{~m}^{2}$; for spraying, $0,009 \mathrm{~m}^{2}$; volumes treated for vacuum-pressure, $135 \times 10^{-6}$ for specimens $1,5 \mathrm{~cm}$ thick, and $54 \times 10^{-5}$ for specimens $6 \mathrm{~cm}$ thick.

The retention after vacuum-impregnation indicated a higher uptake in pine $\left(650 \mathrm{~kg} / \mathrm{m}^{3}\right)$ than in spruce $(250$ $\mathrm{kg} / \mathrm{m}^{3}$ ), in line with previously measured on similar softwood species (Civardi et al. 2015). The higher number of bordered pits and open pits in pine explains in large part this discrepancy. It is worth noting that increasing the thickness of the specimens from $1,5 \mathrm{~cm}$ to $6 \mathrm{~cm}$ did not significantly affect the yields of uptake, suggesting that penetration was limited.

\section{Active agents penetration and retention are influenced by wood micro-anatomy}

Tracing the ingress of the pesticide products within the specimens was first evaluated visually by examination of the color contrast appearing on the transverse section of the samples (Figure 2). In all specimens, irregular delineation of the impregnated zone was observed, indicating the uneven penetration of the preservative formulation.

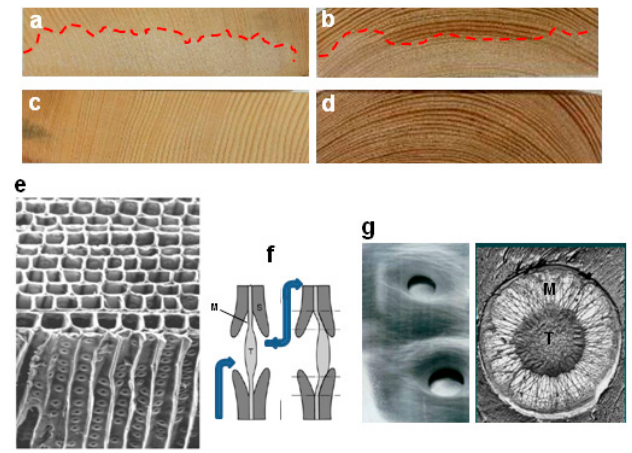

Figure 2: Visual observation of XILIX ${ }^{\circledR}$ LabF2018_008 gel formulation penetration in specimens of spruce and pine wood impregnated by spraying process. Dotted line delineates penetration in spruce (a) and pine (b) sprayed on one face, underscoring the non-homogenous penetration due to local anatomical structure in wood. (c) spruce, and (d) pine, show a more complete impregnation when the specimens were impregnated on two faces; (e - g) illustrate the anatomy and the functioning of bordered pits. (e) scanning view (f) bordered pit scheme: on the left part, unobstructed pit pair with a torus $(\mathrm{T})$ and a margo $(\mathrm{M})$ - blue arrows indicate liquid passage; on the right, aspirated pit with the margo flexing and obstructing liquid passage $(\mathrm{g})$ on the left part, face view of aspirated bordered pits (FE-SEM micrograph); on the right, face view showing the torus surrounded by the porous pit membrane forming the margo (from Sano 2016).

Such irregularity is imposed by the anisotropy of the multi-cellular wood structure. Tracheids favor uptake in longitudinal direction, whereas resin canals cause lower uptake in the lateral direction. This irregular penetration in longitudinal and transverse directions may be also ascribed in part to the smaller diameter of the tracheids in latewood ( $c a .15 \mu \mathrm{m}$ to $20 \mu \mathrm{m}$ ) compared to early wood (ca. $40 \mu \mathrm{m}$ to $50 \mu \mathrm{m}$ ) (Taylor and Moore 1981). That affects the flow, in agreement with Darcy's law (Siau 1984), as well as the larger number of pit connections between cells in latewood compared to earlywood. Variations of conductivity in ray parenchyma also participate to the irregularity of penetration. It has to be noted that ray tracheids and ray parenchyma cells are ten times more numerous in pine than in spruce (Ulvcrona 2006, Zlahtic et al. 2017). The role of pits in preservative penetration and their influence on permeability have been suggested (Baines and Saur 1985, Usta 2005). After the drying step of the specimens, pine sapwood crossfield pits, between longitudinal tracheids and radial tracheids, become more open contrary to spruce which has less radial tracheids and in which they remain almost unaffected (Johansson and Sehlstedt-Persson 2006). In pine sapwood, penetration and diffusion follow a path through the disrupted pit membranes between large size longitudinal tracheids and ray cells, whereas penetrability in spruce heartwood becomes reduced due to the presence of extractives and resin canals (Garcia-Esteban and De Palacios 2009). The opening or closure of the pits (Figure 2) greatly depends on moisture content (Flynn 1995, Usta and Hale 2003, Usta 2005). Reduction of humidity to around $15 \%$ to $25 \%$ is normally achieved before treatment. Significant reduction in the permeability (Sint et al. 2011) during drying has been related to the aspiration of bordered pits (Booker and Evans 1994, Vinden et al. 2003, Pànek and 
Reinprecht 2011) and the number and repartition of the micropores in the aspired membrane of the pits. Drying facilitates the flow pathway in pine sapwood in which bordered pits are more open after drying than in spruce (Johansson and Sehlstedt-Persson 2006). Pressure treatments may sometimes induce pit opening by the rupture of the membrane, resulting in widening of the opening diameters to ca. $4000 \mathrm{~nm}$ (Siau 1984, Matsunaga et al. 2009). In ray tracheid's, parenchyma cells at the junction of the annual ring often interrupt abruptly the penetration. In spruce, the different-sized tracheid's and the smaller pits reduce penetration. All these anatomical aspects contribute to variations of permeability in longitudinal and transverse directions and partly explain the non-homogeneous penetration of the formulations.-

Direct observation in microscopy, including electron microscopy (Olsson et al. 2001), provides a more detailed account of penetration and retention in the different tissues. Moreover, retention within secondary walls (pore size of about $1 \mathrm{~cm}$ to $30 \mathrm{~nm}$, Yin et al. 2015), has previously been demonstrated in electron microscopy (Civardi et al. 2015) by specific immuno-gold labeling of cypermethrin by transmission electron microscopy (Ruel et al. 2015), and corroborated by Civardi et al. (2016). In this respect, it is noteworthy that the size of the emulsion gels particles (10 nm to $100 \mathrm{~nm}$ ) (Candau 1990) is well tailored to the diameter of the pores in secondary walls.

\section{Quantitative determination of active agents according to penetration depth}

Chemical analysis by GC-MS of samples taken at increasing distance from surface gave a precise appreciation of retention and penetration depth of the respective active agents, cypermethrin, from the liquid AXIL ${ }^{\circledR}$ LAB2013 $131^{\circledR}$, and the gel XILIX ${ }^{\circledR}$ LabF2018 009, allowing monitoring cypermethrin, permethrin and propiconazole, after extraction from the specimens. The higher values of retention of active agents in the spraying process are related to the high amount of the formulation deposited on the surface of the specimens, ca. $500 \mathrm{~g} / \mathrm{m}^{2}$.-

The analytical results demonstrate the higher total uptake (almost double) of active agents in pine wood than in spruce wood. Table 2 shows the retention of the active agent at three penetration depths: within the first $3 \mathrm{~mm}$ from surface, between $3 \mathrm{~mm}$ to $6 \mathrm{~mm}, 6 \mathrm{~mm}$ to $9 \mathrm{~mm}$, and $9 \mathrm{~mm}$ to $12 \mathrm{~mm}$. Both pine and spruce showed a clear negative gradient of retention of the active agent with the distance from the surface.

Table 2: Absorption of active agent in pine (P. sylvestris) and spruce (P. abies); repartition at various depths from surface, according to the mode of application.

\begin{tabular}{|c|c|c|c|c|c|c|c|c|c|}
\hline \multirow{2}{*}{$\begin{array}{l}\text { Impregnation } \\
\text { Process }\end{array}$} & \multirow{2}{*}{$\begin{array}{c}\text { Agent } \\
\text { retention } \\
\left(\mathrm{g} / \mathrm{m}^{2}\right) \\
\text { Pine Spruce }\end{array}$} & \multicolumn{8}{|c|}{ Distribution according to depths $(\%)^{* *}$} \\
\hline & & \multicolumn{2}{|c|}{$\begin{array}{l}0 \mathrm{~mm} \text { to } 3 \mathrm{~mm} \\
\text { Pine Spruce }\end{array}$} & \multicolumn{2}{|c|}{$\begin{array}{l}3 \mathrm{~mm} \text { to } 6 \mathrm{~mm} \\
\text { Pine Spruce }\end{array}$} & \multicolumn{2}{|c|}{$\begin{array}{l}6 \mathrm{~mm} \text { to } 9 \mathrm{~mm} \\
\text { Pine Spruce }\end{array}$} & \multicolumn{2}{|c|}{$\begin{array}{l}9 \mathrm{~mm} \text { to } 12 \mathrm{~mm} \\
\text { Pine Spruce }\end{array}$} \\
\hline Dipping $3 \mathrm{~min}$ & $16,8 \quad 5,8$ & 71 & 65 & \begin{tabular}{l|l} 
& 28 \\
\end{tabular} & 31 & 1 & 4 & & n.d \\
\hline Dipping $3 \mathrm{~min}$ & $16,2 \quad 5,0$ & 72 & 62 & 26 & 36 & 1 & 2 & & n.d \\
\hline Dipping $15 \mathrm{~min}$ & $9,7 \quad 5,7$ & 60 & 58 & 38 & 40 & 1 & 2 & & n.d \\
\hline Dipping $15 \mathrm{~min}$ & $13,8 \quad 6,0$ & 66 & 63 & 33 & 35 & 1 & 2 & & n.d \\
\hline Dipping $15 \mathrm{~min}$ & $10,4 \quad 3,8$ & 55 & 63 & 44 & 47 & 1 & 5 & & n.d \\
\hline $\begin{array}{c}\text { Vacuum- } \\
\text { impregnation (6)* }\end{array}$ & $182,4 \quad 11,5$ & 34 & 83 & 32 & 15 & 27 & 1 & 7 & n.d \\
\hline $\begin{array}{c}\text { Vacuum- } \\
\text { impregnation (6) }\end{array}$ & 202,8 & 31 & - & 30 & - & 29 & - & 11 & - \\
\hline $\begin{array}{c}\text { Vacuum- } \\
\text { impregnation (6) }\end{array}$ & 206,9 & 33 & - & 31 & - & 27 & - & 9 & - \\
\hline \multicolumn{10}{|c|}{ Micro-Emulsion formulation XILIX ${ }^{(8)}$ LabF2018_009 } \\
\hline Surface spraying & 252 & 77 & & 15 & 24 & 6 & 1 & n.d & n.d \\
\hline Surface spraying & 320 & 78 & & 12 & 30 & 9 & 2 & n.d & n.d \\
\hline Surface spraying & 335 & 85 & & 11 & 30 & 5 & 8 & n.d & n.d \\
\hline
\end{tabular}

*Vacuum-impregnation on specimens $6 \mathrm{~cm}$ in thickness

**Percent repartition of retained product at increasing depths n.d: non-detectable

***Values are the mean of three assays. 
The quantitative analysis as a function of depth underscores the impact of the process of application that appears in the percentages of distribution of the active agents according to the distance from the surface. The rather important values discrepancies between the specimens must be ascribed to the differences inherent to wood internal anatomical variations. Thus, in pine wood, it is clear that the insecticide molecule applied by the two surface processes, dipping and spraying, accumulates predominantly within the first $3 \mathrm{~mm}$ from the surface and could not be detected beyond $9 \mathrm{~mm}$. This was less conspicuous in the case of the vacuum-impregnation process (Tripathi and Poonia 2015) in which the air and moisture from wood lumens are evacuated, leading to so-called full cell impregnation (Konopka et al. 2018). This resulted in a more progressive gradient of distribution from the surface inwards, extending beyond $12 \mathrm{~mm}$, as shown by the retention of still about 10 $\%$ of the active agent between $9 \mathrm{~mm}$ to $12 \mathrm{~mm}$ in pine, way higher than by dipping.

A similar trend can be observed for the spraying process, though on a lesser distance since the agents did not penetrate significantly beyond $9 \mathrm{~mm}$. These differences due to the modes of application show that the totally passive diffusion of the dipping process leads to a limited penetration. This was modulated by the duration of dipping on pine wood for 3 minutes or 15 minutes which underscored the influence of the duration of impregnation since in the former condition of $3 \mathrm{~min}$, the retention was maximal at more than $70 \%$ within the first $3 \mathrm{~mm}$, then decreased rapidly to around $27 \%$ in the next $3 \mathrm{~mm}$ up to $6 \mathrm{~mm}$, to be almost null around $6 \mathrm{~mm}$ and beyond. When these two dipping durations were applied to spruce, the effect was not as clear. Importantly, in the thicker board specimens, after 21 days of drying following surface application, the penetration could be observed beyond $2 \mathrm{~cm}$ deep in spruce and $3 \mathrm{~cm}$ deep in pine (Table 3 and Table 4). Such a depth of impregnation shows the good diffusion efficiency of the bio-based gels in boards. Although a difference between pine and spruce is still observed, the extent of diffusion due to micro-emulsion gel formulation was improved for the refractory species compared to previous data with other formulations (Messaoudi et al. 2018).

\section{Monitoring of the specific penetration of cypermethrin, propiconazole and permethrin in the spraying process}

In the formulation XILIX ${ }^{\circledR}$ LabF2018_008, the fungicide propiconazole and the insecticide permethrin, are present at the concentration of about $1,2 \%$ and $0,5 \%$, respectively (i.e., a ratio propiconazole/permethrin of 2,41 ). The fate of these two active molecules in pine and spruce woods treated by spraying was followed by GC-MS analysis. The depth of penetration of each active agent was monitored as a function of distance from the sprayed surface in several specimens $(40 \mathrm{~cm}$ x $20 \mathrm{~cm}$ × $5 \mathrm{~cm}$ ) from different boards, in view of detecting the easiness of diffusion of propiconazole $v s$ permethrin in pine and spruce, respectively.

Table 3: Active products content at different depths of penetration in Pine and Spruce specimens subjected to surface spraying with the preservative gel formulation XILIX ${ }^{\circledR}$ LabF2018_008 formulation*.

\begin{tabular}{|c|c|c|c|c|c|c|}
\hline $\begin{array}{l}\text { Wood } \\
\text { Species }\end{array}$ & $\begin{array}{l}\text { Board }^{* *} \\
\text { Specimen }\end{array}$ & $\begin{array}{c}\text { Humidity } \\
(\%)\end{array}$ & $\begin{array}{c}\text { Depth } \\
\text { of } \\
\text { Analysis }\end{array}$ & $\begin{array}{l}\text { Propiconazole } \\
\text { (mg/100g) }\end{array}$ & $\begin{array}{c}\text { Permethrin } \\
\text { (mg/100g) }\end{array}$ & $\begin{array}{l}\text { Propiconazole/ } \\
\text { Permethrin }\end{array}$ \\
\hline \multirow{3}{*}{ Pine } & A (One face) & 13,4 & $3 \mathrm{~cm}$ & $0,30( \pm 0,05)$ & $0,20( \pm 0,05)$ & 1,5 \\
\hline & $\mathrm{B}$ (One face) & 13,0 & $3 \mathrm{~cm}$ & $0,45( \pm 0,1)$ & $0,17( \pm 0,05)$ & 2,6 \\
\hline & $\begin{array}{c}\mathrm{C} \\
2 \text { faces }\end{array}$ & 17,1 & $3 \mathrm{~cm}$ & $\begin{array}{l}3,1(f, I) \\
1,1(f, 2)\end{array}$ & $\begin{array}{l}2,3(f, 1) \\
1,4(f, 2)\end{array}$ & $\begin{array}{l}1,3(f, 1) \\
0,8(f, 2)\end{array}$ \\
\hline \multirow{6}{*}{ Spruce } & $\mathrm{B}($ One face $)$ & 12,8 & $1 \mathrm{~cm}$ & $13( \pm 2)$ & $7( \pm 3)$ & 1,8 \\
\hline & $\mathrm{C}($ One face $)$ & 13,5 & $1 \mathrm{~cm}$ & $17( \pm 4)$ & $10( \pm 3)$ & 1,7 \\
\hline & $\underset{2 \text { faces }}{\mathbf{A}}$ & 18,0 & $1 \mathrm{~cm}$ & $\begin{array}{l}64,2(f, 1) \\
18,9(f, 2)\end{array}$ & $\begin{array}{l}37,0(f, 1) \\
9,8(f, 2)\end{array}$ & $\begin{array}{l}1,7(f, 1) \\
1,9(f, 2)\end{array}$ \\
\hline & $\mathrm{B}($ One face $)$ & 12,8 & $2 \mathrm{~cm}$ & $13( \pm 4)$ & $7( \pm 3)$ & 1,8 \\
\hline & $\mathrm{C}($ One face $)$ & 13,5 & $2 \mathrm{~cm}$ & $11( \pm 4)$ & $6( \pm 3)$ & 1,8 \\
\hline & $\begin{array}{c}\text { A } \\
2 \text { faces }\end{array}$ & 18,0 & $2 \mathrm{~cm}$ & $\begin{array}{l}23,2(f, I) \\
19,5(f, 2)\end{array}$ & $\begin{array}{l}18,9(f, 1) \\
12,0(f, 2)\end{array}$ & $\begin{array}{l}1,2(f, I) \\
1,6(f, 2)\end{array}$ \\
\hline
\end{tabular}

*XILIX ${ }^{\circledR}$ LabF2018_008 comprised 1,23\% propiconazole and 0,51\% permethrin (i.e. ratio of 2,41).

**A, B and C were specimens taken from three different planks of pine and spruce, respectively, on which samplings of $2 \mathrm{~mm}$ were taken at distances from surface. The values reported are the mean from three specimens per plank $( \pm)$.

***One face: board sprayed one face; 2 faces: boards sprayed one 2 faces. 
The results in Table 3 and Table 4 show the amount of propiconazole and permethrin found at depths of $3 \mathrm{~cm}$ from the surface in pine wood, and $1 \mathrm{~cm}$ and $2 \mathrm{~cm}$ in spruce.

Table 4: Permethrin and propiconazole retention at different depths from surface and uptake in Pine and Spruce boards impregnated by spraying with the gel formulation XILIX ${ }^{\circledR}$ LabF2018_008.

\begin{tabular}{|c|c|c|c|c|c|}
\hline $\begin{array}{l}\text { Wood } \\
\text { Species }\end{array}$ & Specimen & $\begin{array}{l}\text { Distance from } \\
\text { Surface }(\mathrm{cm})\end{array}$ & $\begin{array}{c}\text { Propiconazole } \\
(\mathrm{mg} / \mathrm{kg})\end{array}$ & $\begin{array}{c}\text { Permethrin } \\
(\mathrm{mg} / \mathrm{kg})\end{array}$ & $\begin{array}{c}\text { Propiconazole/ } \\
\text { Permethrin }\end{array}$ \\
\hline \multirow{3}{*}{ Pine } & $P A$ & 0 to 3 & 301 & 212 & 1,4 \\
\hline & $P B$ & 0 to 3 & 229 & 168 & 1,4 \\
\hline & $P C$ & 0 to 3 & 258 & 172 & 1,5 \\
\hline \multirow[t]{2}{*}{ Spruce } & $S A$ & $\begin{array}{c}0 \text { to } 1 \\
1 \text { to } 2 \\
\text { n.d. }\end{array}$ & $\begin{array}{c}99 \\
25 \\
\text { n.d. }\end{array}$ & $\begin{array}{r}60 \\
20 \\
\text { n.d. }\end{array}$ & $\begin{array}{l}1,6 \\
1,3 \\
\text { n.d. }\end{array}$ \\
\hline & $S C$ & $\begin{array}{c}0 \text { to } 1 \\
1 \text { to } 2 \\
2 \text { to } 3 \mathrm{~cm}\end{array}$ & $\begin{array}{c}185 \\
60 \\
\text { n.d. }\end{array}$ & $\begin{array}{c}113 \\
42 \\
\text { n.d. }\end{array}$ & $\begin{array}{l}1,6 \\
1,5 \\
\text { n.d. }\end{array}$ \\
\hline
\end{tabular}

*PA: Pine; board A; SA: Spruce; board A.

They revealed that in all cases, the fraction of permethrin that penetrates was proportionally higher than that of propiconazole, as indicated by the ratios of propiconazole to permethrin lower than that of the ratio of 2,41 in XILIX ${ }^{\circledR}$ LabF2018 008 formulation. This was even more pronounced when spraying was applied to the two faces of the specimens, both for pine and spruce wood. Monitoring the fate of cypermethrin from AXIL $^{\circledR}$ LAB2013_131 ${ }^{\circledR}$ showed the decreasing gradient of its retention according to the distance from surface in both wood species (Table 5). This also showed the deeper penetration (beyond $12 \mathrm{~mm}$ ) in pine when vacuum-pressure was applied. The humidity of the specimens below $20 \%$ may influence the penetrability and conduction since it has been shown that below the fiber saturation point (FSP generally near $30 \%$ ) (Ulvcrona 2006) permanent structural changes occur, mainly concerning border pits. The proportion of earlywood and latewood is an important factor involved in the variations of penetration observed between different boards and specimens from a same log.

The quantitative analysis of half-specimens with dimensions of $48 \mathrm{~cm}$ x $20 \mathrm{~cm}$ x $5 \mathrm{~cm}$ kept for 21 days at $20{ }^{\circ} \mathrm{C}$ and $65 \% \mathrm{RH}$ after spraying was performed on $2 \mathrm{~mm}$ samples taken at distances from the surface compared to the total distribution of the active agents from surface to the same distance (Figure 1 and Table 3 ). In pine specimens, the analysis was done at a distance of $3 \mathrm{~cm}$, and the quantitative amount of propiconazole versus permethrin was another indication of the accumulation of specific pesticide molecules from the surface.

Table 5: Penetration and Retention of Cypermethrin from formulation AXIL ${ }^{\circledR}$ LabF2013_131 in Pine and Spruce wood.

\begin{tabular}{|c|c|c|c|c|c|c|}
\hline \multirow[t]{2}{*}{$\begin{array}{l}\text { Wood } \\
\text { Species }\end{array}$} & \multirow[t]{2}{*}{$\begin{array}{l}\text { Mode of } \\
\text { Application }\end{array}$} & \multirow[t]{2}{*}{$\begin{array}{l}\text { Retention } \\
\mathrm{g} / \mathrm{m}^{2} \mathrm{~kg} / \mathrm{m}^{3}\end{array}$} & \multicolumn{4}{|c|}{$\begin{array}{l}\text { Cypermethrin Retention } \\
\text { at Distance from Surface }\end{array}$} \\
\hline & & & $0 \mathrm{~mm}$ to $3 \mathrm{~mm}$ & 3 to $6 \mathrm{~mm}$ & 6 to $9 \mathrm{~mm}$ & 9 to $12 \mathrm{~mm}$ \\
\hline \multirow{3}{*}{ Pine } & Dipping & 245 & 8 & 3,1 & 1,5 & _ \\
\hline & $\begin{array}{c}\text { Vacuum- } \\
\text { impregnation }\end{array}$ & 650 & 64 & 59 & 54 & 18 \\
\hline & Spraying & 310 & 240 & 38 & 20 & - \\
\hline \multirow{3}{*}{ Spruce } & Dipping & 150 & 3 & 2 & 0,1 & - \\
\hline & $\begin{array}{l}\text { Vacuum- } \\
\text { impregnation }\end{array}$ & 730 & 12 & 3 & 0,3 & - \\
\hline & Spraying & 250 & 180 & 69 & 7 & _ \\
\hline
\end{tabular}


The ratios of propiconazole/permethrin, both at $3 \mathrm{~cm}$ and within the first $3 \mathrm{~cm}$ from surface, inferior to the ratio of 2,41 in the applied original formulation, show that permethrin is preferentially fixed at all depths of penetration (Table 5). The same trend was observed in spruce with ratios of the same order of magnitude but always lower in the easily impregnable species. The low moisture content of the specimens, below FSP, suggests that pyrethrin compounds, cypermethrin and permethrin, the less water soluble of the three agents (quasi null for cypermethrin, $5,5 \mathrm{mg} / \mathrm{L}$ for permethrin versus $100 \mathrm{mg} / \mathrm{L}$ for the triazole compound propiconazole; (SPEX CertiPrep 2016) penetrate more easily the hydrophobic lignified network of secondary walls. This, together with their difference in polarity, makes the pyrethrin agents penetrate more easily the lignified cell secondary walls. This suggests that, due to the high lignin content of softwood tracheids and xylem, giving them a significant hydrophobicity, the transportation of the more water-insoluble agents is facilitated. All that indicates the influence of the chemical nature and polarity of the active pesticide agents on their respective penetration and retention.

\section{CONCLUSIONS}

Using our bio-based liquid and gel microemulsion formulations of wood preservatives, surface application by dipping resulted in only a slightly higher retention in $\mathrm{g} / \mathrm{m}^{2}$ in pine than in spruce specimens, contrary to the larger difference in uptake observed when a driving force was involved in the procedure as in spraying and mostly vacuum-impregnation processes. Thus, in the purely surface process, the retention was maximal (around $70 \%$ or more) within the first millimeters from the surface of impregnation, then decreases rapidly. Conversely, when a pressure is exerted, as in the vacuum-impregnation mode, penetration is more homogeneous and deeper and progressively extends deeper up. In fact, simple dipping corresponds to passive diffusion of the preservative agents since only direct surface contact is involved, in the absence of external applied force. Diffusion is thus limited to the accessible natural liquid paths in the wood structure, largely dependent on the sapwood-heartwood ratio and to the degree of pore interconnectivity, the so-called tortuosity, controlled by the status of the bordered pits.

Importantly, after a drying period of 21 days following surface application, the significant diffusion in spruce and pine board specimens shows the efficiency of the bio-based emulsion gels. It underscores the improved impregnation due to the specific composition of these aqueous gel formulations in both the penetrable and the refractory species. In this process, the low particle size of the droplets in the microemulsion gels makes these better vectors and allows better stability and penetration of preservative agents. This efficient impregnation by formulation XILIX ${ }^{\circledR}$ LabF2018_008 supports its observed biological efficacy (data not shown).

The anatomical characteristics of penetrable and refractory softwood species respectively, explain the different impregnability observed between pine and spruce wood. Interestingly, the vacuum-impregnation process, corresponding to full-cell impregnation tends to reduce the difference between the penetrability of the two species by forcing the product to a maximal absorption, thereby warranting a better protection of the wood.

The present work highlights the positive role of liquid and gel microemulsions. It shows correlations between penetration and wood species microstructure under various modes of application. Although the relation between preservative penetration and wood anisotropic structure is complex, the present results should be of practical importance to enhancing the efficacy of wood preservation treatments by controlling the factors pointed out in this work. It also shows the better diffusion of cypermethrin and permethrin than that of propiconazole, illustrating the efficiency of the emulsion gels on the diffusion capacity of the insecticide agents. Altogether, these data will be useful for estimating the capacity of penetration and retention of a type of preservative formulation and its potential of protection according to the wood species.

\section{REFERENCES}

ASTM. 2020. Standard Test Methods for Determining the Biobased Content of Solid, Liquid, and Gaseous Samples Using Radiocarbon Analysis. ASTM D6866. 2020. ASTM: West Conshohocken, PA, USA. 
http://www.astm.org/cgi-bin/resolver.cgi?D6866-20.

Baines, E.F.; Saur, J. 1985. Preservative treatment of spruce and other refractory species.

In Annu Proc Am Wood Preserv Assoc. 1985. Granbury, TX, USA. American Wood-Preservers'Association. 81: 136-147.

Booker, R.E.; Evans, J.M. 1994. The effect of drying schedule on the radial permeability of Pinus radiata D. Don. Holz Roh Werkstoff 52: 150-156. https://doi.org/10.1007/BF02615211.

Candau, F. 1990. An introduction to polymer colloids. In Scientific methods for the study of polymer colloids and their applications. Candau, F.; Ottewill, R.H. (eds). Kluwer Academic Publishers. p. 73.

Civardi, C.; Schwarze, F.W.M.R.; Wick, P. 2015. Micronized copper wood preservatives: An efficiency and potential health risk assessment for copper-based nanoparticles. Environ Pollut 200: 126-132. https://doi.org/10.1016/j.envpol.2015.02.018.

Civardi, C.; Van den Bulcke, J.; Schubert, E.; Michel, M.; Butron, M.I.; Boone, M.N.; Dierick, M.; Van Acker, J.; Wick, P.; Schwarze, F.W.M.R. 2016. Penetration and Effectiveness of Micronized Copper in Refractory Wood Species. PLoS One 11(9): e0163124. https://doi.org/10.1371/journal.pone.0163124.

Comstock, G.A.; Côté Jr, W.A. 1968. Factors affecting permeability and pit aspiration in coniferous sapwood. Wood Sci Technol 2: 279-291. https://doi.org/10.1007/BF00350274.

Du, X.; Lucia, L.A.; Ghiladi, R.A. 2016. A novel approach for rapid preparation of monophasic microemulsions that facilitates penetration of woody biomass. ACS Sustain Chem Eng 4(3): 1665-1672. https://doi.org/10.1021/acssuschemeng.5b01601.

EN. 2016. Durability of wood and wood-based products - Testing and classification of the durability to biological agents of wood and wood-based materials. EN 350. 2016. CEN: Brussels, Belgium. https://www.cen.eu/Pages/default.aspx.

EN. 2017. EN 16640-X85-002-2017: Bio-based products - Determination of the biobased carbon content of products using the radiocarbon method. CEN: Brussels. Belgium https://standards.iteh.ai/catalog/standards/cen/53004db7-e85b-433a-9ed5-5aaed4242fde/en-16640-2017.

EN NF. 2004. Agents de surface - détermination de la tension superficielle. AFNOR normalization Editions: France. EN NF 14370. 2004. https://www.boutique.afnor.org/norme/nf-en-14370/agents-de-surface-determination-de-la-tension-superficielle/article/791494/fa114462

Evans, P. 2003. Emerging technologies in wood protection. Forest Prod $J$ 53(1): 14-22. https://search.proquest.com/docview/214641686?pq-origsite=gscholar\&fromopenview=true

Flynn, K.A. 1995. A review of the permeability, fluid-flow, and anatomy of spruce (Picea spp.). Wood Fiber Sci 27(3): 278-284. https://wfs.swst.org/index.php/wfs/article/view/1659.

Garcia-Esteban, L.; De Palacios, P. 2009. Comparative wood anatomy in Abietoideae (Pinaceae). Bot $J$ Linn Soc 160: 184-196. https://doi.org/10.1111/j.1095-8339.2009.00971.x.

Griggs, J.L.; Rogers, K.R.; Nelson, C.; Luxton, T.; Platten, W.E.; Bradham, K.D. 2017. In vitro bioaccessibility of copper azole following simulated dermal transfer from pressure-treated wood. Sci Total Environ 598: 413-420. https://doi.org/10.1016/j.scitotenv.2017.03.227.

Haller, K.K.; Ventikos.; Poulikakos, D. 2002. Computational study of high-speed liquid droplet impact. J Appl Phys 92: 2821-2828. https://doi.org/10.1063/1.1495533.

Hass, P.; Wittel, F.K.; Stampanoni, M.; Kastner, A.; Mannes, D.; Niemz, P. 2009. 3D characterization of adhesive penetration into wood by Means of synchrotron radiation. In Proceedings of the International Conference on Wood Adhesives. September 28-30, 2009. Lake Tahoe, Nevada, USA. Frihart, C.R.; Hunt, C.G.; Moon, R.J. (Eds.). Forest Products Society: Madison, WI, USA. pp 348-352. 
Johansson, D.; Sehlstedt-Persson, M. 2006. Effect of heat treatment on capillary water absorption of heat-treated pine, spruce and birch. In Wood structure and properties. Proceedings of the 5th IUFRO Symposium Wood Structure and Properties. September 3-6, 2006, Sliač - Sielnica, Slovakia. Lagana, R.; Kurjatko, S.; Kudela, J. (Eds.). Arbora Publishers: Zvolen, Slovakia. pp 251-255.

Kang, S.M.; Morrell, J.J.; Simonsen, J.; Lebow, S. 2005. Creosote movement from treated wood immersed in fresh water. Forest Prod J 55(12): 42-46. https://www.fs.usda.gov/treesearch/pubs/27107.

Konopka, A.; Barański, J.; Orłowski, K.; Szymanowski, K. 2018. The effect of full-cell impregnation of pine wood (Pinus sylvestris L.) on changes in electrical resistance and on the accuracy of moisture content measurement using resistance meter. BioResources 13(1): 1360-1371. https://ojs.cnr.ncsu.edu/index.php/ BioRes/article/view/BioRes_13_1_1360_Konopka_Full_Cell_Impregnation_Pine_Wood.

Koran, Z. 1989. Anatomy and treatability of spruce wood. In Proceedings 1988 Forintek wood preservation seminar, November 4, 1988, Vancouver, Canada. pp 23 - 41.

Lehringer, C.; Richter, K.; Schwarze, F.W.M.R.; Militz, H. 2009a. A review on promising approaches for liquid permeability improvement in softwoods. Wood Fiber Sci 41(4):373-385. https://wfs.swst.org/index.php/wfs/article/view/683.

Lehringer, C.; Arnold, M.; Richter, K.; Schubert, M.; Schwarze, F.W.M.R.; Militz, H. 2009b. Bioincised wood as substrate for surface modifications. In The Fourth European conference on wood modification. Englund, F.; Hill, C.A.S.; Militz, H.; Segerholm B.K. (Eds.), SP Technical Research Institute of Sweden, Stockholm, Sweden. pp. 197-200.

Matsunaga, H.; Kiguchi, M.; Evans, P.D. 2009. Microdistribution of copper-carbonate and iron oxide nanoparticles in treated wood. J Nanopart Res 11: 1087-1098. https://doi.org/10.1007/s11051-008-9512-y.

Messaoudi, D.; Jame, P.; Oberlin, C. 2018. Développement de solutions biosourcées innovantes pour la durabilité conférée des matériaux face aux agents biologiques. In FIBRA Innovation Congrès International de la Construction Biosourcée - Halle Pajol - Paris 18 - France - 3-4 October. Fibra international. BioBuild Concept.

Mohamad-Shahimin M.F.; Siddique T. 2017. Methanogenic biodegradation of paraffinic solvent hydrocarbons in two different oil sands tailings. Sci Total Environ 583: 115-122. https://doi.org/10.1016/j.scitotenv.2017.01.038.

Nyrén, V.; Back, E. 1960. Characteristics of parenchymateous cells and tracheidal ray cells in Picea abies Karst. Svensk Papperstidning 63(16):501-509.

Obounou Akong, F.; Gérardin, P.; Thévenon, M-F.; Gérardin-Charbonnier, C. 2013. State of progress of utilization of supramolecular gels for formulations of water-soluble wood preservation salts. In Proceedings IRG Annual Meeting, IRG/WP 13-30630. The International Research Group on Wood Protection: Stockholm, Sweden.

Olsson, T.; Megnis, M.; Varna, J.; Lindberg, H. 2001. Study of the transverse liquid flow paths in pine and spruce using scanning electron microscopy. J Wood Sci 47(4): 282-288. https://doi.org/10.1007/BF00766714.

Pànek, M.; Reinprecht, L. 2011. Bacillus subtilis for improving spruce wood impregnability. BioResources 6(3): 2912-2931. https://ojs.cnr.ncsu.edu/index.php/BioRes/article/view/BioRes_06_3_2912_ Panek_R_Bacillus_Spruce_Impregnability/1053

Rhatigan, R.; Freitag, C.; El-Kasmi, S.; Morrell, J.J. 2004. Preservative treatment of Scots pine and Norway spruce. Forest Prod J 54(10): 91-94. https://search.proquest.com/docview/214627166?pq-origsite=gscholar\&fromopenview $=$ true

Richardson, B.A. 1993. Wood Preservation. Second edition. E \& FN SPON, Chapman \& Hall London: London. 
Ruel, K.; Tapin-Lingua, S.; Messaoudi, D.; Fahy, O.; Jequel, M.; Petit-Conil, M.; Joseleau, J.P. 2015. Probing biocide penetration and retention in wood products by immulabeling techniques. In Proceedings Wood Science and engineering in the third millennium, International Conference $10^{\text {th }}$ edition. November 5-7, ICWSE 2015. Gurau, L.; Campean, M.; Ispas, M. (Eds.). Transilvania University, Brasov, Romania.

Sano, Y. 2016. Bordered Pit Structure and Cavitation Resistance in Woody Plants. In Secondary Xylem Biology, Origins, Functions, and Applications. Chapter 7: 113-130. https://doi.org/10.1016/B978-0-12-802185-9.00007-3.

Sarpap SA. 1995. Brevet FR 2740659. Composition de préservation pour les bois et son utilisation. SARPAP SA : Marais Ouest, Gardonne, France.

Siau, J.F. 1984. Transport processes in wood. Springer Verlag: Berlin. 243 p.

Sint, K.M.; Militz, H.; Hapla, F.; Adamopoulos, S. 2011. Treatability and penetration indices of four lesser used myanmar hardwoods. Wood Res-Slovakia 5: 13-22. http://www.woodresearch.sk/wr/201101/02.pdf.

SPEX CertiPrep. 2016. Guide to solubility. SPEX CertiPrep Certified Reference Materials - Inorganic and Organic Standards: NJ, USA.

https://www.spexcertiprep.com/knowledge-base/files/Guide-to-Pesticide-Solubility.pdf

Taylor, F.W.; Moore, J.S. 1981. A comparison of earlywood and latewood tracheid length in Loblolly pine. Wood Fiber Sci 13(3): 159-165. https://wfs.swst.org/index.php/wfs/article/view/1995.

Teng, T.J.; Mat Arip, M.N.; Kumar, S.; Nemoikina, A.; Jalaludin, Z.; Ng, E.P.; Lee, H.L. 2018. Conventional Technology and Nanotechnology in Wood Preservation: A Review. BioResources 13(4): 9220-9252. https://ojs.cnr.ncsu.edu/index.php/BioRes/article/view/BioRes_13_4_Teng_Review_Conventional_Technology_Nanotech_Wood.

Tripathi, S.; Poonia, P.K. 2015. Treatability of Melia composita using vacuum pressure impregnation. Maderas-Cienc Tecnol 17(2): 373-384. http://dx.doi.org/10.4067/S0718-221X2015005000035.

Ulvcrona, T. 2006. Impregnation of Norway spruce (Picea abies L. Karst.) wood with hydrophobic oil. Ph.D. Thesis, Swedish University, Umea, Sweden. https://pub.epsilon.slu.se/1214/.

Usta, I. 2005. A review of the configuration of bordered pits to stimulate the fluid flow. Maderas-Cienc Tecnol 7(2): 121-132. http://dx.doi.org/10.4067/S0718-221X2005000200006.

Usta, I.; Hale, M.D. 2003. Radial permeability of Sitka spruce as affected by wood structure: Permeability of cross-field pits in unideriate rays. IAWA $J$ 24(2): 197-204. https://doi.org/10.1163/22941932-90000332.

Vinden, P.; Romero, J.; Torgovnikov, G. 2003. A method for increasing the permeability of wood. US patent 6: 596-975. Application Number: 09/719294 https://patents.google.com/patent/US6596975B1/en.

Wardrop, A.B.; Davies, G.W. 1961. Morphological factors relating to the penetration of liquids into wood. Holzforschung 15(5): 129-141. https://doi.org/10.1515/hfsg.1961.15.5.129.

Yin, J.; Song, K.; Lu, Y.; Zhao, G.; Yin, Y. 2015. Comparison of changes in micropores and mesopores in the wood cell walls of sapwood and heartwood. Wood Sci Technol 49: 987-1001. https://doi.org/10.1007/s00226-015-0741-9.

Zlahtic, M.; Mikac, U.; Sersa, I.; Merela, M.; Humar, M. 2017. Distribution and penetration of tung oil in wood studied by magnetic resonance microscopy. Ind Crop Prod 96: 149-157. http://dx.doi.org/10.1016/j.indcrop.2016.11.049.

Zhang, Y.L.; Zhang, S.Y.; Dian, Q.Y.; Wan, H. 2006. Dimensional stability of wood polymer composites. J Appl Polym Sci 102(6): 5085- 5094. https://doi.org/10.1002/app.23581. 